\title{
Altered Antibody Isotype in Cystic Fibrosis: Possible Role in Opsonic Deficiency
}

\author{
RICHARD B. MOSS, YAO-PI HSU, MARGARET M. SULLIVAN, AND NORMAN J. LEWISTON
}

Ross Mosier Laboratory for Cystic Fibrosis Research, Division of Allergy-Immunology and Respiratory Medicine, Department of Pediatrics, Stanford University Medical School, Palo Alto, California 94304

\begin{abstract}
Patients with cystic fibrosis (CF) whose respiratory tracts are colonized with Pseudomonas aeruginosa (PA) may develop a specific opsonic deficiency for alveolar macrophage phagocytosis of PA. We examined the possible role of altered antibody $(\mathrm{Ab})$ isotype in this phenomenom by measuring serum levels and distribution of IgG and IgG subclass Ab (IgG1, IgG2, IgG3, and IgG4) to the major opsonic immunodeterminant, serotype-specific lipopolysaccharide (LPS), by means of enzyme-linked immunosorbent assays employing monoclonal secondary antibodies, and comparing these results to the serum opsonic capacity in an in vitro murine alveolar macrophage phagocytic assay. Twenty-one patients with $C F$ who were colonized with PA had approximately a 30-fold elevation of PA LPS IgG Ab levels and higher IgG subclass 1-4 Ab compared to 10 uncolonized patients with $C F$ and 11 healthy controls $(p<0.05-0.0005$ depending on the isotype). Colonized patients with CF had a shift in PA LPS Ab distribution toward IgG3 compared to uncolonized patients with $\mathrm{CF}(\boldsymbol{p}<\mathbf{0 . 0 2})$. A surprising finding was that uncolonized patients with $C F$ had lower levels $(p<0.05)$ and proportion $(p<0.002)$ of PA LPS IgG2 Ab than controls, with an apparent shift to higher levels and proportion of PA LPS IgG4 $(p<0.01)$. Serum from colonized patients with CF showed diminished opsonic capacity for phagocytosis of PA compared to uncolonized patients and controls $(p<0.005)$, with $42 \%$ showing inhibitory activity. Functional $\mathrm{Ab}$ was also found to be inhibitory at high (> $500 \mathrm{ng} / \mathrm{ml}$ ) concentrations. Serum opsonic capacity appeared to include a noncomplement cofactor for optimal activity. Levels of PA LPS IgG4 but not IgG1-3 subclass Ab correlated inversely with opsonic capacity. We conclude that high levels of PA LPS IgG4 Ab may be inhibitory to normal pulmonary clearance of $\mathrm{PA}$ in colonized patients with $C F$, and that high levels of functional antibodies may also contribute to this specific acquired deficiency. The role of deficient IgG2 Ab responses to PA LPS and possibly other polysaccharide antigens in $\mathrm{CF}$ requires further study. (Pediatr Res 20: 453-459, 1986)
\end{abstract}

Abbreviations

Ab, antibody

CF, cystic fibrosis

PA, Pseudomonas aeruginosa

Received September 16, 1985; accepted January 8, 1986.

Correspondence Richard B. Moss, M.D., Children's Hospital-Stanford, 520 Sand Hill Road, Palo Alto, CA 94304.

Supported in part by research grants from the Cystic Fibrosis Foundation and Cystic Fibrosis Research, Inc.

${ }^{1}$ Portions of this work were presented at annual meetings of American Thoracic Society (Am Rev Respir Dis 131:A22, 1985), the Cystic Fibrosis Club (CF Club Abstr 26:23, 1985), and the Western Society for Pediatric Research (Clin Res $34: 131 \mathrm{~A}, 1986)$.
LPS, lipopolysaccharide

ELISA, enzyme-linked immunosorbent assay

PBS, phosphate-buffered saline

Patients with CF are vulnerable to chronic endobronchial colonization and subsequent persistent infection with PA. The factors underlying this vulnerability are not understood. Various PA surface or secretory properties have been proposed to play a role in chronic pulmonary infection, including increased adherence to CF respiratory epithelium (1), mucoid exopolysaccharide production and subsequent microcolony formation (2), loss of $O$-side chain determinants from surface lipopolysaccharide (3), and production of a number of extracellular proteases or toxins $(4,5)$. On the host side, no generalized immune deficiency has been identified (6). However, a specific deficiency in serum and respiratory fluid opsonizing capacity for alveolar macrophage phagocytosis of PA has been described in colonized patients (79). This deficiency can be duplicated using affinity-purified $\mathrm{CF}$ serum and respiratory fluid IgG antibodies to PA lipopolysaccharide $(10,11)$, which is the normally opsonic immunodeterminant (12). The clinical significance of this finding has not been established.

Recently, Fick et al. (11) proposed that the mechanism of this opsonic deficiency may be degradation of IgG into dysfunctional fragments by PA-derived elastase, a proteolytic enzyme. This hypothesis is supported by experiments showing degradation of IgG by PA elastase in vitro $(13,14)$ and fragmentation of PA LPS IgG antibody from bronchial lavage fluid of CF patients in vivo (11).

There are, however, reasons to doubt proteolysis as the central mechanism of opsonic deficiency in CF. The defect occurs in serum and serum-derived antibodies where immunoglobulin fragmentation cannot be detected by the most sensitive physicochemical methods (7-10). In addition, Döring et al. $(15,16)$ have shown that antibodies to PA elastase are present in high titers in serum as well as bronchial fluid of colonized CF patients and neutralize its proteolytic activity. Finally, and perhaps most importantly, there is an apparent microbial antigenic specificity in the defect, i.e. CF antibodies to other bacteria are fully opsonic $(8,9,17,18)$. It is difficult to see how proteolytic activity with IgG as a substrate would exhibit a clonal specificity.

An alternative mechanism involves an alteration in the isotypic pattern of antibody response which might lead to inefficient antigen-specific opsonization. Aalberse et al. (19) have described such isotypic alterations in antibody responses following prolonged immunization with certain antigens in vivo in humans, in which production of IgG subclass 4 antibodies predominate.

We have previously described elevated serum IgG4 antibodies to undefined PA antigens in colonized patients with CF (20). Herein, we extend these findings to all IgG subclasses using new 
highly specific and sensitive monoclonal antibody-based immunoassays, focusing on the LPS antigen of PA, and comparing the serum antibody isotypic response to opsonizing capacity in colonized and uncolonized CF patients and healthy controls.

\section{METHODS}

Serum samples. Serum samples were obtained by venipuncture from 31 patients with $\mathrm{CF}$ attending the Stanford CF Center clinic. Twenty-one patients ( 12 males, nine females, ages 4.8$42.5 \mathrm{yr}$, mean 23.4) were classified as chronically colonized with PA on the basis of three or more positive sputum cultures of at least 1 yr duration. Ten patients without PA colonization (five males, five females, ages 1.6-26.8 yr, mean 18.2) were also studied. Only three of these patients were under $16 \mathrm{yr}$ of age. Eleven healthy controls consisted of adult hospital workers (physicians, nurses, and therapists) who had daily contact with $\mathrm{CF}$ patients. Blood $(10-20 \mathrm{ml})$ was collected in glass tubes, allowed to clot at room temperature, centrifuged at $2000 \mathrm{rpm}$ for $10 \mathrm{~min}$, and the serum decanted. Serum was aliquoted and frozen at $-70^{\circ} \mathrm{C}$ until tested.

Serum PA LPS IgG antibodies. Serum levels of IgG antibodies were measured by quantitative microtiter plate ELISA standardized by intraplate antiisotype curves (21). The LPS antigen employed was the Parke-Davis vaccine containing the seven Fisher-Devlin serotype-specific immunodeterminants (22). Polyvinylchloride microtiter plate wells (Dynatech, Alexandria, VA) were coated with $20 \mu \mathrm{g} / \mathrm{ml}$ PA LPS in normal saline for 1 $h$ at $37^{\circ} \mathrm{C}$ and aspirated. For each pair of antigen-coated wells, a pair of control wells received saline without antigen. After blocking with $0.1 \%$ human serum albumin-PBS- $0.01 \%$ thimerosal for $1 \mathrm{~h}$ at $37^{\circ} \mathrm{C}$ and aspiration, wells were washed three times with PBS-0.05\% Tween 20-thimerosal, aspirated, and air dried. Test sera diluted 1:100, 1:500, and 1:1000 in 10\% normal goat serum-PBS-thimerosal (dilution buffer) were then incubated for $2 \mathrm{~h}$ at $22^{\circ} \mathrm{C}$. After aspiration and washing, wells were incubated with affinity-purified goat antihuman $\mathrm{IgG}$-peroxidase conjugate (Sigma, St. Louis, MO) 1:1000 in dilution buffer for 1 $\mathrm{h}$ at $37^{\circ} \mathrm{C}$. Following aspiration and washing, wells were then developed with $0.5 \mathrm{mg} / \mathrm{ml}$ ortho-phenylenediamine, $0.012 \%$ hydrogen peroxide substrate in phosphate-citrate buffer pH 6 at $22^{\circ}$ $\mathrm{C}$ for $10 \mathrm{~min}$. The reaction was stopped with $5 \mathrm{~N}$ sulfuric acid and read at 490 nanometers in a microtiter spectrophotometer (Bio-Tek, Burlington, VT). Net absorbance was calculated by subtracting the mean absorbance of paired saline control wells from each pair of antigen-coated wells.

Antibody levels were derived by interpolation of test serum net absorbance values to a standard curve generated in two rows of wells on each plate using $20 \mu \mathrm{g} / \mathrm{ml}$ affinity-purified goat $\mathrm{F}\left(\mathrm{ab}^{\prime}\right)_{2}$ antihuman IgG $\mathrm{F}\left(\mathrm{ab}^{\prime}\right)_{2}$ (Cappel, West Chester, PA) as the antigen exposed to paired doubling dilutions $(640-10 \mathrm{ng} / \mathrm{ml})$ of purified human polyclonal IgG (Miles Research Products, Elkhart, IN) and developed identically to test sera. Linear parallelism of test sera and standard curve dilutions were verified by semilogarithmic plots and slope analysis. Final results in mass units $(\mu \mathrm{g} / \mathrm{ml})$ were obtained by interpolation of absorbance values to the standard curve and multiplication by the appropriate dilution factor. The coefficient of variation (using 1:500 and 1:1000 dilutions for high-titer sera, and 1:100 and 1:500 for lowtiter sera) was usually $<20 \%$. The intraplate coefficient of variation for standard curves was $16 \%$.

Serum PA LPS IgG subclass 1-4 antibodies. Serum levels of IgG subclass 1-4 antibodies were measured by amplifed microtiter plate ELISA employing high affinity, subclass-specific, noncross-reactive murine IgG1 monoclonal antibodies as described in detail elsewhere (23). Of critical importance was verification of subclass specificity and insensitivity to allotypic determinants, which were demonstrated for the monoclonal secondary antibodies used in this study by both direct binding and inhibition experiments with a panel of purified human myelomas. In order to allow semiquantitative comparisons of relative amounts and contribution of each subclass antibody to the total, the dilution of each monoclonal antibody employed was adjusted to yield identical net absorbance values ("equipotency") in primary interaction with a purified homologous human IgG subclass myeloma pool, adsorbed to wells at equal concentrations, when simultaneously and identically developed (24). In brief, the ELISA was performed as described above with the following changes: 1) sera were diluted $1: 10$ and $1: 50 ; 2$ ) murine antihuman IgG subclass $1,2,3$ or 4 monoclonal antibodies were incubated overnight at $22^{\circ} \mathrm{C}$ at equipotent dilutions; 3) goat antimouse IgG-peroxidase conjugate 1:1000 (Boehringer Mannheim, Indianopolis, IN) was the detector. The monoclonal antibodies and dilutions employed were as follows: for anti-IgG1, clone 0912 , lot 360199 (Hybritech, La Jolla, CA), 1:6000; for anti-lgG2, Seward clone GOM-1, lot 2 (distributed by Miles Laboratories, Naperville, IL), 1:8000; for anti-IgG3, clone 68PC1A11, lot 40309 (Bethesda Research Laboratories, Gaithersburg, MD), 1:15000; and for anti-IgG4, clone Sk-44, lot 1 (Bio-Yeda, Rehovot, Israel), 1:2000.

Because myeloma-antibody subclass standard curves show variable affinities and thus differing dilution slopes, standardization in mass units may not be accurate (25). Results are therefore given in net absorbance values to yield comparable estimates of IgG subclass antibody concentrations and contribution to the class total.

Opsonophagocytosis assay. A phagocytic uptake assay of radiolabeled PA by mouse alveolar macrophages adherent to glass on short-term culture was modified from the methodology of Reynolds and Thompson (12).

Radiolabeling of $P A$. For these studies a sputum isolate (HA1) from a CF patient was employed. This strain was selected on the basis of stability of the mucoid phenotype on repeated subculturing, polyagglutinability by the Fisher-Devlin and IATS typing schemes, and resistance to bactericidal activity of $5 \%$ fresh normal human serum. The strain was stored in glycerol at $-20^{\circ}$ C. For each opsonophagocytosis assay, an aliquot of stock culture was thawed and grown overnight in a mixture of minimal essential medium without leucine- $10 \%$ newborn calf serum-2 $\mathrm{mM}$ L-glutamine- $5 \mathrm{mcC} / \mathrm{ml}^{3} \mathrm{H}$-leucine at $37^{\circ} \mathrm{C}$ with continuous gentle shaking. After washing three times with phosphate buffered saline and centrifuging $2500 \mathrm{rpm}$ for $15 \mathrm{~min}$, the cells were suspended in PBS and diluted 10-fold serially to $10^{-9}$. One $\mathrm{ml}$ per dilution from $10^{-4}$ to $10^{-9}$ was plated on MacKonkey medium to obtain bacterial density $(\mathrm{cfu} / \mathrm{ml})$. Fifty mcl was counted in a scintillation counter to obtain labelling efficiency. Cells were diluted to $10^{9} \mathrm{cfu} / \mathrm{ml}$ for the assay.

Opsonization. One hundred mcl PA suspension $\left(10^{8}\right.$ cells) were incubated with $1 \mathrm{ml}$ opsonin in Hanks' balanced salt solution-gel at $37^{\circ} \mathrm{C}$ for $30 \mathrm{~min}$ with continuous gentle shaking. The solution was then centrifuged $2500 \mathrm{rpm}$ for $15 \mathrm{~min}$, followed by decanting of the supernatant and suspension of the pellet to $1 \mathrm{ml}\left(10^{8} \mathrm{cells} / \mathrm{ml}\right)$ in Hanks' balanced salt solution-gel.

Opsonins employed included serum at various dilutions, a hyperimmune Pseudomonas globulin preparation kindly provided by Dr. Michael Collins at Cutter Laboratories, Berkeley, CA (26), and purified IgG fractions of serum prepared by standard ammonium sulfate precipitation and DEAE ion exchange chromatography. Purity of $\mathrm{IgG}$ fractions was assessed by double diffusion and immunoelectrophoresis using appropriate antisera, and sodium dodecyl sulfate-polyacrylamide gel electrophoresis.

Isolation and culture of mouse alveolar macrophages. Twenty Swiss-Webster mice ( $30 \mathrm{~g}$ ) were sacrificed per experiment. Lungs were excised, dissected, and the parenchyma carefully minced for $10 \mathrm{~min}$ at room temperature (27). The minced tissue was then mixed in medium $199-100 \mathrm{U} / \mathrm{ml}$ of penicillin-streptomycin-heparin $10 \mathrm{U} / \mathrm{ml}$ ("complete M199") for $20 \mathrm{~min}$ at room temperature and passed through a fine screen mesh. Cells were then centrifuged $1000 \mathrm{rpm}$ for $10 \mathrm{~min}$ and the supernatant decanted. After addition of $5 \mathrm{ml} 0.83 \%$ ammonium chloride, 
recentrifugation and three washings of the pellet with complete M199, the final pellet was resuspended in $20 \mathrm{ml}$ complete M199$10 \%$ heat-inactivated mouse serum. The cell count was adjusted to yield a final concentration of $1-5 \times 10^{6}$ mononuclear cells per culture chamber. After adjustment, the cells were incubated $3 \mathrm{~h}$ at $37^{\circ} \mathrm{C}$ and washed twice with M199. Then $0.5 \mathrm{ml}$ complete M199 was added to each chamber and the cells cultured overnight at $37^{\circ} \mathrm{C}$ in a $5 \% \mathrm{CO} 2$ incubator.

Phagocytosis assay. After overnight incubation, chambers were microscopically inspected for macrophage adherence, number, and viability. The cells were then washed twice with M199. After $250 \mathrm{mcl} / \mathrm{chamber}$ of Hanks' balanced salt solution was added, $100 \mathrm{mcl} / \mathrm{chamber}$ of the bacterial preparation was added (bacteria: macrophage ratio approximately 10:1) and incubated for the desired time, usually $30 \mathrm{~min}$, at $37^{\circ} \mathrm{C}$. An aliquot was sampled at the beginning of the experiment to determine the bacterial counts per minute added per chamber. Following incubation of bacteria with macrophages, the chambers were vigorously washed seven times with PBS. The chambers were then placed upon an ice bed and macrophages lysed with distilled water. (In some experiments, PBS-1\% Triton X-100 was used.) The chambers were then thoroughly scraped with a rubber policeman to remove any adherent unlysed cells and $200 \mathrm{mcl}$ of the solution transferred to a scintillation fluid vial. All assay samples were run in duplicate with each experiment incorporating a nonopsonic uptake baseline and negative controls (bacteria with medium alone). The percent phagocytic uptake was calculated as $\mathrm{cpm}$ in the final cell chamber lysate/cpm of bacteria added $\times 100$.

To assess possible error due to adherence of uningested bacteria, sample chambers were air-dried, stained with WrightGiemsa stain, and examined by oil-immersion microscopy $(1000 \times)$ for presence of intracellular bacteria. Bacteria were visualized within macrophages in samples with positive radiolabel uptake and not seen in negative control samples without uptake. Also, independent analysis of this methodology by scanning electron microscopy showed only a small number $(6 \%)$ of adherent, uningested bacteria (10).

Statistical methods. Data were analyzed using the two-tailed paired $t$ test for sample means, the $\chi^{2}$ test for proportions, and Spearman's rank correlation coefficient. $P$ values of less than 0.05 were considered significant. Variance is expressed throughout this report as the SEM. To increase the sensitivity of opsonophagocytosis data for statistical analysis of antibody correla- tions, results were expressed as the percent change from the nonopsonic uptake of unopsonized bacteria by macrophages for each serum opsonic source in the experiment.

\section{RESULTS}

Serum levels of IgG antibodies to PA LPS were highly elevated $(p<0.0005)$ in colonized CF patients. The mean level in this group, $161 \pm 30 \mu \mathrm{g} / \mathrm{ml}$, was elevated approximately 30 -fold over uncolonized $\mathrm{CF}$ patients and healthy hospital personnel controls $(4.3 \pm 4.2$ and $2.6 \pm 2.7 \mu \mathrm{g} / \mathrm{ml}$, respectively).

Serum IgG1-4 subclass PA LPS antibody levels were compared semiquantitatively using net absorbance values in ELISA. The summated PA LPS IgG1-4 subclass antibody values correlated strongly with independently determined PA LPS IgG levels $(r=$ $0.85, p<0.0001)$. As shown in Table 1 , colonized CF patients had significantly elevated antibody levels of all four IgG subclasses when compared to either uncolonized $\mathrm{CF}$ patients or controls. Uncolonized CF patients were found to have significantly lower serum levels of PA LPS IgG2 antibodies $(p<0.05)$ and higher levels of PA LPS IgG4 antibodies $(p<0.01)$ than normal controls (Table 1).

The distribution of antibody isotype is independent of antibody concentration (i.e. there will be a certain distribution at any given set of concentrations) and represents a potentially important opsonic variable. We therefore also analyzed PA LPS IgG1-4 antibodies by comparing the percent of the total IgG antibody contributed by each subclass. As shown in Table 2, colonized CF patients had a significantly greater portion of their IgG antibodies in the IgG3 subclass as compared to uncolonized patients $(25 \pm 4$ versus $7.2 \pm 4.5 \%, p<0.02)$ as well as healthy controls, whose mean PA LPS IgG3 portion was $3.6 \pm 1.9 \%$. When uncolonized $\mathrm{CF}$ patients were compared to controls, they were again found to have relatively less $\mathrm{IgG} 2$ and more $\mathrm{IgG4}$ antibody as determined by distribution of the subclasses (for $\mathrm{IgG} 2,29.6 \pm 8.5$ versus $68.5 \pm 6.1 \%, p<0.002$; for $\mathrm{IgG} 4,53.6$ \pm 6.7 versus $25.5 \pm 5.5 \%, p<0.01$ ). Thus, differences in distribution of antibody isotypes between study groups were similar to differences in concentrations of antibody isotypes.

The opsonizing capacity of serum was assessed using an assay of mouse alveolar macrophage uptake of radiolabeled mucoid PA. Preliminary experiments established that the optimal concentration of opsonin varied depending on the antibody titer of the source. For example, Figure 1 shows a representative exper-

Table 1. Serum IgG subclass 1-4 antibody levels to PA lipopolysaccharide in colonized and uncolonized CF patients and controls (net absorbance $\pm S E M$ )

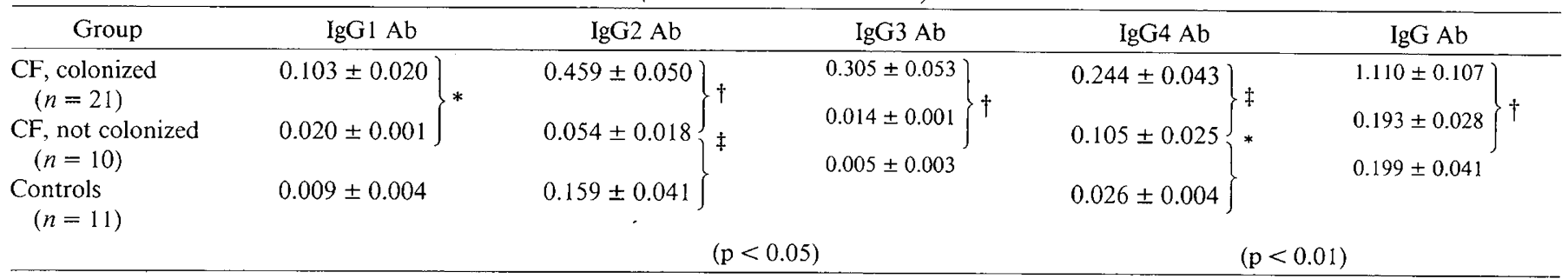

$$
\begin{aligned}
& * p<0.01 . \\
& \dagger p<0.001 . \\
& \ddagger p<0.05 .
\end{aligned}
$$

\begin{tabular}{|c|c|c|c|c|}
\hline Group & $\operatorname{IgGl~Ab}$ & $\operatorname{IgG} 2 \mathrm{Ab}$ & $\operatorname{IgG} 3 \mathrm{Ab}$ & $\mathrm{IgG} 4 \mathrm{Ab}$ \\
\hline $\begin{array}{l}\mathrm{CF} \text {, colonized } \\
\mathrm{CF} \text {, not colonized } \\
\text { Controls }\end{array}$ & $\begin{array}{l}8.8 \pm 1.6 \\
9.5 \pm 4.0 \\
7.5 \pm 3.3\end{array}$ & $\left.\begin{array}{l}44.7 \pm 4.3 \\
29.6 \pm 8.5 \\
68.5 \pm 6.1\end{array}\right\} \dagger$ & $\left.\begin{array}{c}25.0 \pm 4.0 \\
7.2 \pm 4.5 \\
3.6 \pm 1.9\end{array}\right\} *$ & $\left.\begin{array}{l}45.3 \pm 25 \\
53.6 \pm 6.7 \\
25.5 \pm 5.5\end{array}\right\}$ \\
\hline
\end{tabular}

Table 2. Distribution of serum IgG subclass 1-4 antibodies to PA lipopolysaccharide in colonized and uncolonized CF patients and controls (\% total IgG $A b \pm S E M$ )

\footnotetext{
$* p<0.02$.

$\dagger p<0.002$.

$\ddagger p<0.01$.
} 


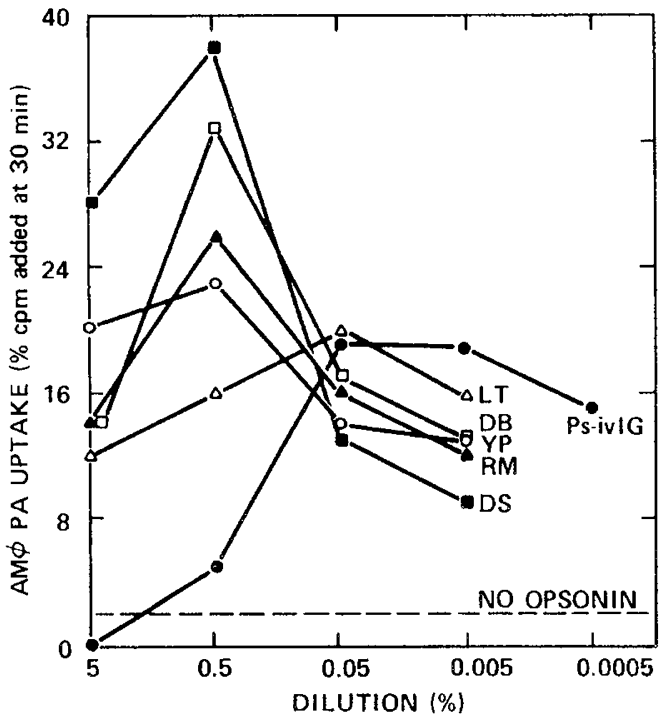

Fig. 1. Murine alveolar macrophage phagocytosis of PA with serially diluted sera from three colonized patients with CF (LT, DB, and DS) and two controls (YP, RM) compared with a Pseudomonas hyperimmune $\gamma$-globulin preparation $(P s-i v I G)$ as opsonins in one experiment. Note that at $5 \%$ dilution of opsonins the Ps-ivIG is inhibitory, and that optimal opsonization occurs at varying dilutions for different antibody sources; these optimal dilutions appear primarily dependent upon the level of PA LPS IgG antibody (see text).

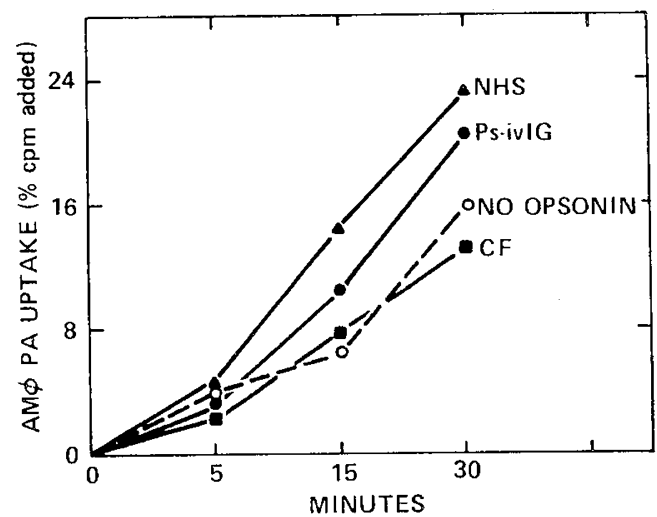

Fig. 2. Phagocytic kinetics of murine alveolar macrophage phagocytosis of PA with opsonins prediluted to equal $(50 \mathrm{ng} / \mathrm{ml})$ antigen-binding titers of PA LPS IgG antibody. Serum from a colonized patient with CF remained inhibitory despite removal of prozone effect by equalization of antibody titer to optimal concentration. $N H S$, normal control serum; $P$ s-ivIG, Pseudomonas hyperimmune $\gamma$-globulin; no opsonin, uptake of unopsonized PA.

iment comparing five sera and Pseudomonas hyperimmune globulin at various concentrations: in general, low titer PA LPS IgG antibody sources showed optimal opsonizing capacity in the range of $0.5-5 \%$ while high titer sources needed further dilution to achieve maximal uptake.

To minimize the prozone effect, several experiments were conducted using opsonic sources prediluted to yield equivalent PA IgG LPS antigen-binding titers. Figure 2 illustrates such an experiment using approximately $50 \mathrm{ng} / \mathrm{ml}$ PA LPS IgG antibody (optimal opsonic range in the assay was $25-250 \mathrm{ng} / \mathrm{ml}$ ). Despite ablution of the prozone effect, the PA-colonized CF serum source was inferior to both normal serum and Pseudomonas hyperimmune globulin as an opsonin and at $30 \mathrm{~min}$ showed a mild inhibitory effect. In general, sera from colonized patients showed quite variable opsonic capacity, ranging from inhibition to substantial enhancement, after equititer predilution.
The effect of complement was examined in experiments in which fresh serum $(n=12)$ was compared to autologous serum heat-inactivated at $56^{\circ} \mathrm{C}$ for $30 \mathrm{~min}$. No significant reduction in opsonizing capacity was noted, indicating that the assay was relatively complement-independent for the bacterial strain and phagocyte employed. In contrast, phagocytic uptake by human peripheral blood leukocytes (primarily neutrophils) was found to be complement dependent (data not shown).

Serum from $19 \mathrm{PA}$-colonized $\mathrm{CF}$ patients, nine noncolonized patients, and nine controls were compared for opsonic capacity using a 5\% dilution and 30-min uptake time (9). Although we had determined that antibody concentration does have an effect on phagocytosis (Fig. 1), a uniform dilution (i.e. containing different antibody concentrations from different individual sera) was chosen to more closely simulate in vivo conditions, where different concentrations of opsonins are available to phagocytic cells in lungs of different individuals. Figure 3 shows the results of these experiments. Phagocytosis was significantly depressed in the colonized CF patients (mean 30-min uptake $=10.7 \pm 0.9 \%$ cpm added) as compared with the uncolonized CF patients and controls (whose sera had similar opsonic activity, combined mean uptake $=17.7 \pm 1.1 \%, p<0.005$ ). Eight of 19 colonized CF sera showed 30-min uptake values below the unopsonized control, i.e. they were inhibitory, as compared to one of 18 uncolonized CF patient and control sera $\left(\chi^{2}, p<0.05\right)$. The single CF patient not colonized with PA whose serum showed inhibitory activity was colonized with Pseudomonas cepacia.

IgG was purified by ammonium sulfate precipitation and ion exchange chromatography from serum of six colonized CF patients, four uncolonized patients, and one healthy control. The isolates in all cases showed two bands on sodium dodecyl sulfatepolyacrylamide gel electrophoresis with molecular weights corresponding to intact heavy and light IgG chains. PA LPS IgG in isolates reconstituted to original volume showed about $40 \%$ of the serum antibody level as determined by ELISA of samples before and after isolation. (This was nonspecific protein loss as indicated by paired Lowry total protein determinations.) The opsonic capacity of IgG fractions from the colonized and uncolonized patients was now similar $(12.0 \pm 1.2$ versus $13.1 \pm 0.4 \%$, respectively), indicating loss of opsonizing capacity with no effect on the inhibitory factor(s). These results suggest possible non-

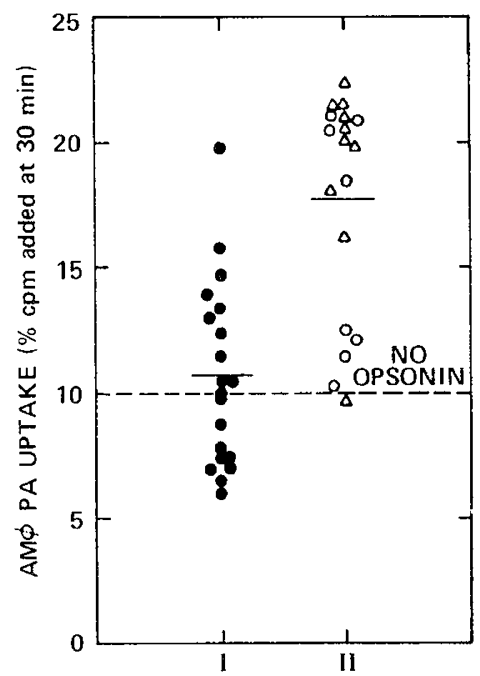

Fig. 3. Opsonization of PA by $5 \%$ sera from 19 colonized patients with CF (I, filled circles), nine uncolonized patients with CF (II, open triangles), and nine healthy controls (II, open circles). Points represent murine alveolar macrophage phagocytosis at $30 \mathrm{~min}$, expressed as cpm associated with macrophage/cpm added to chamber $\times 100$. The mean uptake in group I was $10.7 \pm 0.9$ versus $17.7 \pm 1.1 \%$ in group II $(p<$ $0.005)$. The mean PA LPS IgG Ab level in group I was $168 \pm 34$ versus $4.4 \pm 0.7 \mu \mathrm{g} / \mathrm{ml}$ in group II $(p<0.0005)$. 
complement serum opsonic cofactors for optimal alveolar macrophage phagocytosis of mucoid PA.

Twenty-four CF patients for whom PA LPS IgG1-4 subclass antibody levels and opsonic data were determined were divided into two groups based on enhancement or inhibition of phagocytosis. As shown in Table 3, the nine CF patients with inhibitory serum activity for PA phagocytosis had significantly higher levels of PA IgG4 Ab $(p<0.05)$ but not other subclasses when compared to the 15 patients whose serum enhanced phagoyctosis. This suggested an inhibitory effect of IgG4 antibody, which appeared to be a function of concentration rather than distribution of antibody isotype because differences in phagocytosis were not reflected in distribution as they were in concentration.

We therefore correlated PA LPS IgG4 subclass antibody levels to phagocytic uptake results (Fig. 4). An inverse correlation was found between PA LPS IgG4 subclass Ab level and phagocytic uptake in these 24 patients and six controls for whom complete data was determined $\left(\mathrm{R}_{\mathrm{s}}=-0.38, p=0.02\right)$. A slightly weaker but significant inverse correlation was found between PA LPS IgG level and phagocytic uptake $\left(\mathrm{R}_{\mathrm{s}}=-0.32, p=0.04\right)$. No significant positive or negative correlations were found between uptake and PA LPS IgG1-3 levels.

\section{DISCUSSION}

Chronic bronchopumonary disease in CF can be divided into two related processes, initial endobronchial colonization and subsequent infection primarily confined to conducting airways and surrounding tissues. The initial process probably involves a change in adherence properties relatively specific for the respiratory epithelial cells or secretions and microbial pathogens involved (28). The reasons for this remain obscure but presumably reflect the underlying molecular pathobiology of the disease. After initial colonization, the second process, characterized by local inflammation and an immune response, raises a new question of failed pulmonary clearance mechanisms in the face of intact systemic immunity (6).

Pulmonary clearance of PA in mammalian models depends on an interaction of opsonic antibody directed primarily against immunodeterminants on the cell wall LPS and resident alveolar macrophages (12). This opsonic antibody is initially secretory IgA but is soon superseded by more effective IgG antibody (29). Much of the IgG antibody is probably produced by plasmacytes in regional lymph nodes and arrives in the bronchial lumen via transudation from serum which is enhanced by inflammation (30). As failed pulmonary clearance in CF does not appear to be due to alterations in intrinsic mucociliary clearance or macrophage function $(6,17)$, the opsonic antibody response has been implicated.

In 1971, Biggar et al. (7) described an opsonic defect for PA in the serum of $\mathrm{CF}$ patients with rabbit alveolar macrophages but not normal human neutrophils as the phagocytic cells. This has been subsequently confirmed with other mammalian (including human) alveolar macrophages $(8,9)$, and shown to be specific for PA. Fick et al. $(10,11)$ have implicated deficient interaction of LPS-specific IgG antibodies with alveolar macrophage receptors as a likely source of the deficiency and have extended earlier work with serum to bronchial lavage-derived antibodies. This interaction occurs between the $\mathrm{CH} 2$ domain of the $\mathrm{Fc}$ portion of the $\mathrm{IgG}$ molecule and corresponding $\mathrm{Fc} \lambda$ receptors on the phagocytic cell surface (31). In a cat model of chronic bronchopulmonary PA infection, Winnie et al. (32) have described the development of specific opsonic deficiency in infected animals in association with development of high titers of PA LPS IgG antibodies (33).

Our interest in the possibility that isotypic antibody alterations could play a role in the opsonic defect in CF was awakened by reports of altered immunoglobulin isotypes, particularly elevation of IgG4 subclass protein (34). Our preliminary findings of elevated PA-specific IgG4 subclass antibody in colonized patients (20) led us to examine the IgG1-4 subclass antibody response to PA LPS in relation to opsonic deficiency. We hypothesized that the IgG4 subclass isotype was the best candidate for defective antibody for a number of reasons: prominence in high-dose, prolonged immunization situations (19); poor complement activating and $\mathrm{Fc}$ receptor binding abilities $(31,35,36)$; and by analogy to recent findings in other clinical conditions of chronic antigenemia such as filariasis, schistosomiasis, hypersensitivity pneumonitis, and allergic aspergillosis (37-40). We found that while colonized CF patients demonstrated elevated serum levels of all four IgG subclass antibodies to PA LPS, only IgG4 subclass antibody concentration correlated inversely with opsonic deficiency for mouse alveolar macrophage phagocytosis of PA, suggesting that this isotype may in fact be inhibitory to optimal pulmonary clearance of PA.

A number of other salient findings have emerged from these studies. First, we have extended the demonstration of the serum opsonic deficiency in colonized CF patients to the murine alveolar macrophage using a convenient lung mince preparative procedure. Previously, rabbit, rat, cat, and human alveolar macrophages have been employed.

Second, we have confirmed a potentially important prozone phenomenom in which high concentrations of functional antibody decrease phagocytosis. This may have implications for in vivo pulmonary clearance of $\mathrm{PA}$, as colonized $\mathrm{CF}$ patients develop extreme (ca. 30 -fold) elevations of LPS IgG antibody. Such prozone effects have been reported in phagocytic assays with functional monoclonal antibody opsonins (41). Our phagocytic studies were conducted with a uniform $5 \%$ dilution of sera (i.e. varying antibody concentrations from different subjects) to conserve this effect which probably is operative in vivo.

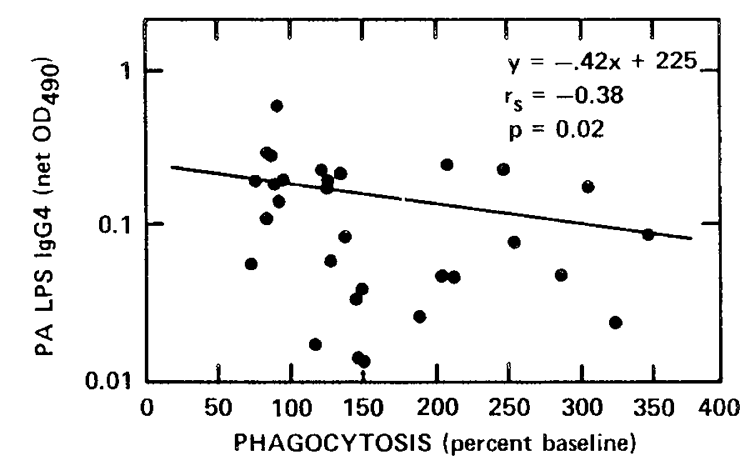

Fig. 4. Phagocytosis of PA (abscissa) in relation to levels of PA LPS $\mathrm{IgG}$ subclass 4 antibody (ordinate). Phagocytic uptake at $30 \mathrm{~min}$ for each serum opsonic source is expressed as a percent of uptake by macrophages of unopsonized PA (baseline, i.e. $<100 \%$ is inhibitory).

Table 3. Serum IgG subclass 1-4 antibodies to PA lipopolysaccharide in CF patients in relation to serum opsonizing capacity (inhibitory or enhancing) for mouse alveolar macrophage phagocytosis of PA (net absorbance \pm SEM)

$\left.\begin{array}{ccccc}\hline \text { Group } & \operatorname{IgG} 1 \mathrm{Ab} & \operatorname{IgG} 2 \mathrm{Ab} & \operatorname{IgG} 3 \mathrm{Ab} & \mathrm{IgG} 4 \mathrm{Ab} \\
\hline \begin{array}{c}\text { Inhibitory } \\
(n=9)\end{array} & 0.118 \pm 0.036 & 0.378 \pm 0.099 & 0.235 \pm 0.094 & 0.224 \pm 0.048 \\
\begin{array}{c}\text { Enhancing } \\
(n=15)\end{array} & 0.050 \pm 0.015 & 0.297 \pm 0.076 & 0.176 \pm 0.020 & 0.126 \pm 0.020\end{array}\right\} *$\begin{tabular}{c}
$*$ \\
\hline
\end{tabular}

$* p<0.05$. 
Third, we have noted a decrease in the opsonic capacity of IgG isolated from serum which does not appear to be due to complement, implying the possible need for noncomplement serum cofactors for optimal opsonization of PA for alveolar macrophage phagocytosis. Such cofactors have been described, e.g. fibronectin (42), and might explain puzzling discrepancies in prior studies of opsonization by CF sera (7-9).

A surprising finding in this study was that uncolonized $\mathrm{CF}$ patients appear to mount a subnormal IgG2 and supranormal IgG4 PA LPS subclass antibody response whether analyzed in terms of quantity or proportion (Tables 1 and 2). As these were mainly older patients, it is doubtful that the lower IgG2 subclass antibody responses were a result of maturational effects on the isotypic pattern (43). If these results are confirmed in larger sample sizes, a number of intriguing possibilities would be raised: could the changes noted be due to immunogenetic differences between $\mathrm{CF}$ patients and normals? Immunoglobulin isotype levels are affected not only by antigenic exposure and age, but also gender, race, and genetic differences detectable with immunoglobulin allotypic markers (44). Could the changes observed reflect suboptimal responses to other IgG2-restricted polysaccharide antigens, indicating a subtle underlying humoral immune deficiency? There are no data on IgG subclass antibody responses to other protein or polysaccharide antigens in CF patients, but such studies could quickly shed light on these intriguing possibilities.

It is important to note that while this report has focused on PA LPS and the corresponding immune response, other PA antigens and antibodies may play a key role in overall clearance. For example, Ames et al. (45) have recently shown that rabbit antibodies to purified PA mucoid exopolysaccharide can efficiently opsonize PA for phagocytosis by human peripheral blood leukocytes.

In conclusion, we have found that $\mathrm{CF}$ patients who are not colonized with PA have lower IgG2 and higher IgG4 subclass antibody responses to PA LPS than healthy controls despite similar overall levels of IgG antibodies. Colonized CF patients develop elevated levels of all four IgG subclass antibodies, especially IgG3, along with deficient opsonic capacity for alveolar macrophage phagocytosis of PA in many. Serum levels of IgG4 subclass antibodies to PA LPS correlate inversely with phagocytosis, suggesting that this antibody isotype may block efficient uptake of PA by macrophages. This possibility adds further complexity to a situation where other factors may be at work, including the inhibitory role of inappropriately high concentrations of antibody as well as the potential role of proteolytic enzymes in the respiratory tract.

Acknowledgments. The authors thank Lawrence Simon, M.D. for assistance with the phagocytic assays and Lewis Perelmutter, Ph.D. for review of the manuscript.

\section{REFERENCES}

1. Woods DE, Bass JA, Johanson WG, Straus DC 1980 Role of adherence in the pathogenesis of Pseudomonas aeruginosa lung infection in cystic fibrosis patients. Infect Immun 30:694-699

2. Lam J. Chan R, Lam K, Costerton JW 1980 Production of mucoid microcolonies by Pseudomonas aeruginosa within infected lungs in cystic fibrosis. Infect Immun 28:546-566

3. Hancock RE, Mutharia LM, Chan L, Darveau RP, Speert DP, Pier GB 1983 Pseudomonas aeruginosa isolates from patients with cystic fibrosis: a class of serum-sensitive, nontypable strains deficient in lipopolysaccharide $\mathrm{O}$ side chains. Infect Immun 42:170-177

4. Woods DE, Cryz SJ, Friedman RL, Iglewski BH 1982 Contribution of toxin $\mathrm{A}$ and elastase to virulence of Pseudomonas aeruginosa in chronic lung infections in rats. Infect Immun 36:1223-1228

5. Nicas TI, Frank DW, Stenzel P, Lile JD, Iglewski BH 1985 Role of exoenzyme $\mathrm{S}$ in chronic Pseudomonas aeruginosa lung infections. Eur $\mathrm{J}$ Clin Microbiol 4:175-179

6. Moss RB 1983 Immunology of cyctic fibrosis: immunity, immunodeficiency, and hypersensitivity. In: Lloyd-Still JD (ed) Textbook of Cystic Fibrosis. PSG Inc., Boston, pp 109-151

7. Biggar WD, Holmes B, Good RA 1971 Opsonic defect in patients with cystic fibrosis of the pancreas. Proc Nat Acad Sci USA 68:1716-1719

8. Boxerbaum B, Kagumba M, Matthew LW 1973 Selective inhibition of phagocytic activity of rabbit alveolar macrophages by cystic fibrosis serum. Am Rev Respir Dis 108:777-783

9. Thomassen MJ, Boxerbaum B, Demko CA, Kuchenbrod PJ, Dearborn DG, Wood RE 1979 Inhibitory effect of cystic fibrosis serum on Pseudomonas phagocytosis by rabbit and human alveolar macrophages. Pediatr Res 13:1085-1088

10. Fick RB, Naegel GP, Matthay RA, Reynolds HY 1981 Cystic fibrosis Pseudomonas opsonins. Inhibitory nature in an in vitro phagocytic assay. J Clin Invest 68:899-914

11. Fick RB, Naegel GP, Squier SU, Wood RE, Bernard J, Gee L, Reynolds HY 1984 Proteins of the cystic fibrosis respiratory tract. Fragmented immunoglobulin $\mathrm{G}$ opsonic antibody causing defective opsonophagocytosis. J Clin Invest 74:236-248

12. Reynolds HY, Thompson RE 1973 Pulmonary host defenses. II. Interaction of respiratory antibodies with Pseudomonas aeruginosa and alveolar macrophages. J Immunol 111:369-380

13. Döring G, Obernesser HJ, Botzenhart K 1981 Extracellular toxins of Pseudomonas aeruginosa. II. Effect of two proteases on human immunoglobulins IgG, IgA, and secretory IgA. Zbl Bakt Hyg I Abtst Orig A 249:89-98

14. Fick RB, Baltimore RS, Squier SU, Reynolds JY 1985 IgG proteolytic activity of Pseudomonas aeruginosa in cystic fibrosis. J Infect Dis 151:589-598.

15. Döring G, Obernesser HJ, Botzenhart K, Flehming B, Hфiby N, Hofmann A 1983 Proteases of Pseudomonas aeruginosa in patients with cystic fibrosis. J Infect Dis 147:744-750

16. Döring G, Buhl V, Hфiby N, Schiotz PO, Botzenhart K 1984 Detection of proteases of Pseudomonas aeruginosa in immune complexes isolated from sputum of cystic fibrosis patients. Acta Path Microbiol Scand [C] 92:307312

17. Thomassen MJ, Demko CA, Wood RE, Tandler B, Dearborn DG, Boxerbaum B, Kuchenbrod PJ 1980 Ultrastructure and function of alveolar macrophages from cystic fibrosis patients. Pediatr Res 14:715-721

18. Thomassen MJ, Demko CA, Wood RE, Sherman JA 1982 Phagocytosis of Pseudomonas aeruginosa by polymorphonuclear leukocytes and monocytes: effect of cystic fibrosis serum. Infect Immun 38:802-805

19. Aalberse RC, Van der Gaag R, Van Leeuwen J 1983 Serologic aspects of IgG4 antibodies. I. Prolonged immunization results in an $\mathrm{IgG} 4$-restricted response. J Immunol 130:722-726

20. Moss RB, Hsu YP, Leahy M, Halpern G 1983 IgG4 antibody to Pseudomonas aeruginosa in cystic fibrosis. In: Kerr JW, Ganderton MA (eds) Proceedings of Invited Symposia, XI International Congress of Allergology and Clinical Immunology. Macmillan, London, pp 351-355

21. Zollinger WD, Boslego JW 1981 A general approach to standardization of the solid phase radioimmunoassay for quantitation of class-specific antibodies. $J$ Immunol Methods 46:129-138

22. Hanessian S, Regan W, Watson D, Haskell TH 1971 Isolation and characterization of antigenic components of a new heptavalent Pseudomonas vaccine. Nature New Biol 229:209-210

23. Moss RB, Hsu YP, Kwasnicki B, Sullivan MM, Reid MJ 1985 Isotypic and antigenic specificities of the natural and immunotherapeutic blocking antibody response to Rye grass pollen: correlation of Rye group 1-specific IgG1 with clinical outcome in allergic individuals. J Allergy Clin Immunol (in press)

24. Djurup R, Sondergaard I, Magnusson CGM, Weeke B 1984 A three-layer immunoradiometric assay for determination of IgG subclass antibodies in human sera ("lgG subclass RAST"). Validation of the subclass specificity, and establishment of equipotency. Allergy 39:51-61

25. Seppala IJT, Routonen N, Sarnesto A, Mattila PA, Mäkela O 1984 The percentages of six immunoglobulin isotypes in human antibodies to tetanus toxoid: standardization of isotype-specific second antibodies in solid-phase assay. Eur J Immunol 14:868-875

26. Collins MS, Roby RE 1984 Protective activity of an intravenous immune globulin (human) enriched in antibody against lipopolysaccharide antigens of Pseudomonas aeruginosa. Am J Med 76:168-174

27. Simon LM, Axline SG, Robin ED 1978 The effect of hyperoxia on phagocytosis and pinocytosis in isolated pulmonary macrophages. Lab Invest 39:541-546

28. Pier GB 1985 Pulmonary disease associated with Pseudomonas aeruginosa in cystic fibrosis: current status of the host-bacterium interaction. J Infect Dis 151:575-580

29. Reynolds HY, Kazmierowski JA, Newball HH 1975 Specificity of opsonic antibodies to enhance phagocytosis of Pseudomonas aeruginosa by alveolar macrophages. J Clin Invest 56:376-385

30. Kaltreider HB 1984 Local Immunity. In: Bienenstock J (ed) Immunology of the Lung and Upper Respiratory Tract. McGraw-Hill, New York, pp 191215

31. Alexander MD, Andrews JA, Leslie RGQ, Wood NH 1978 The binding of human and guinea pig IgG subclasses to homologous macrophage and monocyte Fc recepters. Immunology 35:115-123

32. Winnie GB, Klinger JD, Sherman JM, Thomassen JM 1982 Induction of phagocytic inhibitory activity in cats with chronic Pseudomonas aeruginosa pulmonary infection. Infect Immun 38:1088-1093

33. Shryock TR, Sherman JM, Klinger JD, Thomassen MJ 1984 Phagocytic inhibitory activity in serum from lipopolysaccharide immunized cats. CF Club Abstr 25:139

34. Shakib F, Stanworth DR, Smalley CA 1976 Elevated serum IgG4 levels in cystic fibrosis. Clin Allergy 6:237-240 
35. Isenman DE, Dorrington KJ, Painter RH 1975 The structure and function of immunoglobulin domains. II. The importance of interchain disulfide bonds and the possible role of molecular flexibility in the interaction between immunoglobulin $G$ and complement. J Immunol 114:1726-1729

36. Naegel GP, Young KR, Reynolds HY 1984 Receptors for human IgG subclasses on human macrophages. Am Rev Respir Dis 129:413-418

37. Iskander R, Das PK, Aalberse RC 1981 IgG4 antibodies in Egyptian patients with schistosomiasis. Int Arch Allergy Appl Immun 66:200-207

38. Ottesen EA, Skvaril F, Tripathy SP, Poindexter RW, Hussain R 1985 Prominence of $\mathrm{IgG} 4$ in the $\mathrm{IgG}$ antibody response to human filariasis. J Immunol $134: 2707-2712$

39. Calvanico NJ, Ambegaonkar SP, Schlueter DP, Fink JN 1980 Immunoglobulin levels in bronchoalveolar lavage fluid from pigeon breeders. J Lab Clin Med 96:129-140

40. Stokes TC, Turton CWG, Turner-Warwick M 1981 A study immunoglobulin $\mathrm{G}$ subclasses in patients with allergic aspergillosis. Clin Allergy 11:209-215
41. Cross AS, Wooldridge WH, Zollinger WD 1984 Monoclonal antibody 2-2-B kills Kl-positive Escherichia coli in conjunction with cord blood neutrophils and sera, but not spinal fluid. Pediatr Res 18:770-772

42. Hill HR, Shigeoka AO, Augustine NH, Pritchard D, Lundblad JL, Schwartz RS 1984 Fibronectin enhances the opsonic and protective activity of monoclonal and polyclonal antibody against group B Streptococci. J Exp Med 159:1618-1628

43. Schur Ph, Rosen F, Norman ME 1979 Immunoglobulin subclasses in normal children. Pediatr Res 13:181-183

44. Shackelford PG, Granoff DM, Nahm MH, Scott MG, Suarez B, Pandey JP, Nelson SJ 1985 Relation of age, race, and allotype to immunoglobulin subclass concentrations. Pediatr Res 19:846-849

45. Ames P, DesJardins D, Pier GB 1985 Opsonophagocytic killing activity of rabbit antibody to Pseudomonas aeruginosa mucoid exopolysaccharide. Infect Immun 49:281-285 